that did most of the damage in the village.

If that 10-ha ladang had not been cleared, the river above the erosion areas which had an area of $63 \mathrm{sq} \mathrm{m}$ (it drains a catchment area of $400 \mathrm{ha}$ ), would have spread out harmlessly in the wider area near the village, forming a front less than one metre high and over $63 \mathrm{~m}$ wide, compared with the flood which actually hit the village which was $75 \mathrm{~m}$ wide and $4.5 \mathrm{~m}$ high, at a point $530 \mathrm{~m}$ from the village. Thus if 10 ha of forest on that slope had not been logged, 13 people at Lawe Mengkudu would still be alive.

This flood was no freak of nature. The following night, only a few kilometres away at Seldoq, the Lawe Penanggalan flooded. Here the logs that came down did far more damage than at LMK, but not in lives lost. Thirty people took refuge inside the house of Bpk Aman Sar. As the logs came crashing down onto his house, one house a metre away and three houses opposite were squashed. One person was killed; it was very nearly 31 . Other normally small rivers (3-5m wide, $30-50 \mathrm{~cm}$ deep) at Aunan and Lawe Gerger flooded, bringing down a mass of logs which destroyed newly built bridges, houses, roads and rice fields.

The message is clear; most of the small rivers draining into the Alas River from the steep slopes above, descend through narrow steep-sided ravines, which can and do, dam easily when the forest above them is cleared. In the Alas Valley, the logging of forest on the mountain watersheds, must be prohibited, or the toll of people killed will increase.

But this logging continues.

We would like to acknowledge support from the Leverhulme Trust (JMYR) and the Gerritts Foundation (BRS). We are also grateful to the Indonesian Institute of Sciences, and to Ken Proud of WWF-Indonesia.

\title{
Feral Goats in New Zealand
}

\author{
M.R. Rudge
}

New Zealand policy is to eliminate feral introduced animals, such as deer and goats, which have done immense damage to the native animals and vegetation. But an attempt to kill off the feral goats on one island in order to protect the native vegetation raised the cry that these were 'Old English' goats and should be conserved.

The Species Survival Commission (SSC), at its October meetings in New Zealand, departed briefly from discussing endangered species to hear the case for saving what may be an endangered breed, presented by a group on behalf of the feral goats of Arapawa Island in the Marlborough Sound region. The history of these goats is obscure, but they have probably been on the island since 1839 . If they were brought from England, as so many of New Zealand's animals were, they may even be a relic of the Old English breed.

New Zealand has had a long-standing policy of eliminating feral mammals in order to protect native flora and fauna. But when moves were made against these animals, local enthusiasts removed some of them to private land and prompted two government departments to set up a herd for study. Both herds are having breeding problems but the combined number of captive animals is now about 250 . The long-term future of these flocks is still being debated but, for the time being at least, this strain is not in danger of extermination. Quite what the strain is is still in question, but work is continuing to find objective ways of describing differences between New Zealand feral goat populations and their relationship to domestic breeds.

It is most unusual for New Zealand authorities to be even considering the conservation of introduced feral mam- 
mals. Hitherto the entire emphasis has been on eliminating feral animals. It is also commonplace in other parts of the world for feral animals, particularly goats, to be classed as pests and exterminated whenever and wherever it is possible to do so. However, views upon this are changing both within New Zealand and in other parts of the world. IUCN itself has now recognised that feral animals within particular taxonomic groups may be of value and may be worthy of some conservation action. The SSC has set up a working party on feral animals to review the topic and how to deal with feral animal populations in all parts of the world. This interest within IUCN is matched by recent activities from $F A O$ in which rare and endangered breeds including feral animals have been documented.

In the past, New Zealand has been celebrated for the action which it has taken against introduced mammals. It may now be that the country will be

\section{Humpback Sightings in Antarctica}

\section{Nigel Bonner}

Because of their coastal habits and lethargic nature, humpback whales Megaptera novaeangliae have been among the species hardest hit by the whaling industry. Between 1904 and 1973 (when humpback catching finally ceased), 68,294 humpbacks were reported killed in Antarctic waters, more than 40 per cent of these in the first ten years. Humpbacks, which are relatively easy to identify at sea, have been reported from the Antarctic in recent years only rarely. However, it now seems that some recovery may be taking place.

Last Antarctic summer (1980-81) I made 28 humpback sightings from RRS Bransfield, of the British Antarctic Survey, while working on the west coast of the Antarctic Peninsula in the neighbourhood of the Grandidier Channel and the Gerlache Strait. Because the ship was not celebrated for the lead which it is taking in the conservation of certain feral animals. Already a reserve has been created on one of the off-shore islands for a remnant of a feral sheep population, and management plans will be drawn up which will take account of feral populations on other off-shore islands, some of which are nature reserves. Preliminary studies by scientists are indicating that these isolated remnants of domesticated stock which have been abandoned show interesting features when compared with commercial flocks and herds. This scientific work will be continued at the same time that managers seek solutions to the problem of accommodating alien browsing mammals within the system of nature reserves for the protection of native flora and fauna.

Dr M.R. Rudge, Ecology Division, Dept of Scientific and Industrial Research, 66 Bloomfield Terrace, Private Bag, Lower Hutt, New Zealand.

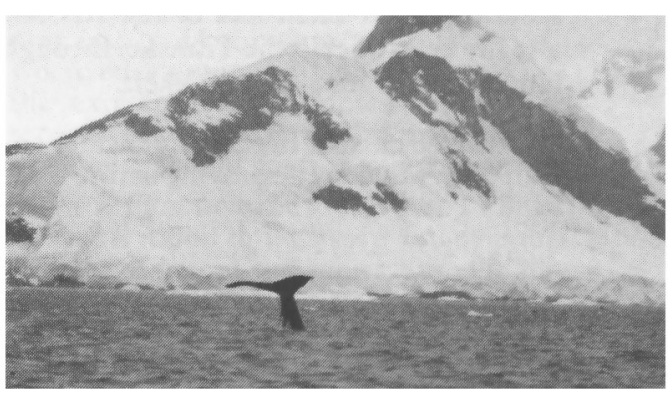

steaming evenly, and I had other duties, it was not possible to make quantified observations from standard watches.

Humpback whales were first sighted on 17th March just to seaward of the Cruls Islands $\left(65^{\circ} 9^{\prime} \mathrm{S}, 64^{\circ} 34^{\prime} \mathrm{W}\right)$ and between 15.40 and 17.00 six were seen, two pairs and two single individuals. Two days later nine sightings were made, in three groups of three whales each. Each group consisted of a large whale, closely accompanied by a smaller one, with another large whale some tens of metres away. Two of these groups were watched swimming northwards along the Grandidier Channel from Cape Tuxen. The third 